\title{
STRUKTUR GENETIK POPULASI IKAN CAKALANG, Katsuwonus pelamis (Linneaus, 1758) DI PERAIRAN LAUT MALUKU UTARA, INDONESIA
}

\section{GENETIC STRUCTURE POPULATIONS SKIPJACK, Katsuwonus pelamis (Linneaus, 1758) IN NORTH MALUKU SEA, INDONESIA}

\author{
Nebuchadnezzar Akbar ${ }^{1 *}$ \& Rusmawati Labenua ${ }^{2}$ \\ ${ }^{1}$ Ilmu Kelautan, FPIK, Universitas Khairun, Ternate, 97719, Indonesia \\ ${ }^{2}$ Manajemen Sumberdaya Perairan, FPIK, Universitas Khairun, Ternate, 97719, Indonesia \\ *E-mail: nezzarnebuchad@yahoo.co.id
}

\begin{abstract}
Genetic is key substantial approach conservation, managament and sustainability. This study aims to genetic structure populations Skipjack tuna in North Maluku Sea. Samples collection in Morotai Island $(n=10)$, Central Halmahera District, Weda $(n=10)$ dan South Halmahera District, Bacan, $(n=10)$ and secondary data $(n=4)$ in March-May 2018. Molecular analysis through stages extraction, PCR, electrophoresis and sequencing DNA. DNA sequences analysis used MEGA 5 (Genetic distance and phylogenetic) and arlequin (Fixation index). The result found that fragment length 546 (base pairs) in control mitocondrial DNA. Genetic distance analysis Skipjact tuna population based on primary (North Maluku) and secondary data (Sulu-Celebes and South China Sea, Bali, Indian coast, Kyushu Island Japan) show close genetic 0.037-0.056. Fixation indices (Fst) analysis value 0.8010.936 the show that weak genetic differentiation between populations. High genetic flow between populations based on genetic distance and Fst. The result show that genetic distance and Fst show that genetic structure populations Skipjack tuna in North Maluku Sea undistrubed. The Skipjack tuna data obtained can uses data base to preserve and sustainability fish resource.
\end{abstract}

Keywords: conservation, genetic, North Maluku, skipjack

\begin{abstract}
ABSTRAK
Genetik merupakan suatu pendekatan untuk pemanfaatan, pengelolaan dan keberlanjutan yang bersifat konservasi. Tujuan penelitian adalah struktur populasi genetik ikan cakalang di perairan laut Maluku Utara. Koleksi sampel dilakukan pada Pulau Morotai $(\mathrm{n}=10)$, Weda, Kabupaten Halmahera Tengah $(\mathrm{n}=10)$, Bacan, Kabupaten Halmahera Selatan $(\mathrm{n}=10)$ dan data sekunder $(\mathrm{n}=4)$, pada Maret hingga Mei 2018. Analisis molekuler melalui tahapan ektraksi, PCR, elektroforesis dan pengurutan DNA (sekuensing DNA). Sekuen DNA kemudian dianalisis menggunakan MEGA 5 (jarak genetik dan filogenetik) serta Arlequin 3.5 (fiksasi indeks). Hasil penelitian menemukan panjang fragmen DNA 546 (base pairse) di daerah lokus control region DNA Mitokondria (mtDNA). Analisis jarak genetik populasi berdasarkan data primer (Maluku Utara) dan sekunder (Sulu-Celebes dan South China Sea, Bali, Indian coast, Kyushu Island Japan) dengan nilai 0,037-0,056. Analisis fiksasi indeks (Fst) diperoleh nilai 0,801-0,936 yang menunjukkan bahwa tidak terdapat diferensiasi genetik antar populasi. Aliran genetik yang besar antar populasi berdasarkan hasil analisis jarak genetik dan Fst. Hasil analisis menunjukkan bahwa struktur genetik populasi ikan cakalang di perairan Maluku belum terganggu. Data genetik ikan cakalang yang diperoleh dapat dijadikan sebagai basis data untuk melestarikan dan menjaga keberlanjutan sumber daya ikan.
\end{abstract}

Kata kunci: Cakalang, genetik, konservasi, Maluku Utara

\section{PENDAHULUAN}

Perairan Maluku Utara adalah daerah potensial penangkapan ikan pelagis. Daerah ini dipengaruhi oleh arus lintas Indonesia yang membawa massa air subur dari Samudra Pasifik masuk ke perairan Indonesia dan mengalir hingga Samudra Hindia. 
Kementerian Kelautan dan Perikanan pada tahun 2015 menyebutkan bahwa salah satu sumber daya perikanan yang dieksploitasi di peraiaran ini adalah ikan cakalang ( $K$. pelamis). Ikan cakalang memiliki total produksi 57.126,3 ton di perairan Maluku Utara. Kementerian Kelautan dan Perikanan pada tahun 2015 menyebutkan bahwa potensi sumber daya cakalang di Maluku Utara baru di manfaatkan sekitar 48,54\%. Ikan Cakalang merupakan target dalam dalam operasi penangkapan di daerah Indonesia. Setiap tahunnya produksi ikan cakalang di Indonesia meningkat, sehubungan dengan kebutuhan permintaan pasar. Kegiatan seperti ini dapat memberikan dampak terhadap kualitas dan kuantitas sumber daya ikan cakalang. Sektor perikanan merupakan sumber daya dapat pulih (renewable resources), akan tetapi laju pemanfaatan tidak seimbang terhadap tingkat kecepatan pertumbuhan pemulihan. Maluku Utara masuk dalam WPP-RI 714-716, sehingga perlu suatu pendekatan untuk meminimalisir terjadinya degradasi populasi ikan cakalang. Beberapa daerah potensial ikan cakalang seperti Pulau Bacan, Obi, Morotai dan Ternate telah memberikan indikasi dan dugaan adanya penurunan hasil tangkap dan ukuran ikan tertangkap.

Pendekatan pengelolaan, pelestarian dan pemanfaatan secara bekelanjutan dapat dimulai melalui kajian substansial seperti genetik. Informasi struktur genetik dapat digunakan untuk melihat kestabilan dan status kesehatan populasi. Penelitian tentang genetika populasi itu sendiri, terutama menyangkut keragaman genetika ikan di Indonesia, telah dilakukan diantaranya studi genetika populasi ikan kakap merah (Lutjanus malabaricus) yang berasal dari beberapa daerah penangkapan Pantai Utara Jawa dan Laut Jawa bagian timur (Soewardi \& Suwarso, 2006), tuna sirip kuning (Thunnus albacores) dari daerah Bali, Maluku Utara dan Sulawesi Utara (Permana et al., 2007), kajian struktur populasi tuna mata besar di Samudra Hindia bagian Sumatra Barat, Selatan Jawa dan Nusa Tenggara yang dilakukan oleh Suman et al. (2013), studi variasi genetik pada tuna sirip kuning yang di kaji berdasarkan dua populasi di laut Maluku, Indonesia (Akbar et al., 2014).

Penelitian struktur populasi ikan cakalang berdasarkan tingkat populasi telah dilakukan oleh Toatubun et al. (2015) di perairan Manado. Sedangkan penelitian tentang genetik ikan cakalang baru dilakukan oleh Fakhri et al. (2015) dari Kabupaten Jembrana dan Karangasem, Bali”. Penelitian Akbar et al. (2018) tentang keragaman genetik ikan cakalang di perairan Maluku Utara, namun informasi tentang ikan cakalang khususnya struktur genetik populasi belum tersedia. Kajian tentang struktur genetik penting, karena dapat memberikan informasi pertukaran genetik pada populasi berbeda, dengan demikian status populasi dapat ditentukan. Selain itu pengetahuan tentang struktur genetik populasi sangatlah baik untuk keberlanjutan dan efektifitas manajemen sumber daya (Chiang et al., 2006; Chiang et al., 2008). Hal ini mendasari dilakukanya penelitian mengenai struktur genetik populasi ikan cakalang ( $K$. pelamis). Penelitian bertujuan mengetahui struktur genetik populasi ikan cakalang (K. pelamis).

\section{METODE PENELITIAN}

\subsection{Waktu, Lokasi Penelitian dan Koleksi Sampel}

Tahapan penelitian meliputi pengambilan sampel, pengambilan sampel, pengerjaan laboratorium dan analisis data. Pengambilan sampel pada Maret-Mei 2018 (Figure 1). Koleksi material DNA pada 30 sampel ikan (pectoral fins) di lokasi Pulau Morotai $(\mathrm{n}=10)$, Weda, Kabupaten Halmahera Tengah $(\mathrm{n}=10)$, Bacan dan Kabupaten Halmahera Selatan $(n=10)$. Sampel yang diperoleh kemudian difoto dan diambil bagian sirip dada sepanjang $3 \mathrm{~cm}$, setelah itu disimpan dalam tabung yang telah terisi etanol $90 \%$ (Akbar et al., 2018). Data sekunder diperoleh melalui GenBank dengan accession number untuk keperluan komparasi (Table 1). 

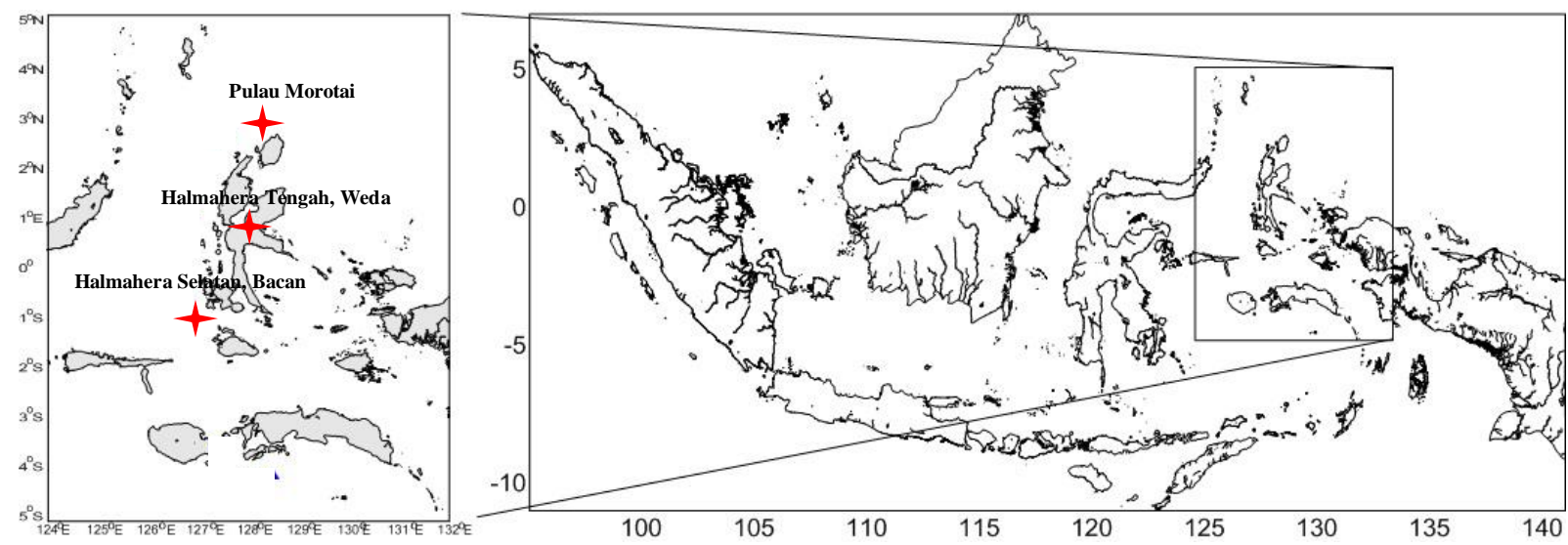

Figure 1. Research locations (Source: Akbar dan Labenua, 2018).

Table 1. Yellowfin tuna secondary data and accession number (GenBank).

\begin{tabular}{|c|c|c|c|}
\hline No. & Authors & Years & Accession number \\
\hline 1 & $\begin{array}{l}\text { A Rahim, M., Basir, S., Musel, J., Mohd } \\
\text { Saleh, M.F. and Abdullah, A.W. }\end{array}$ & 2016 & KY353356.1 \\
\hline 2 & $\begin{array}{l}\text { Yamashita, H., Yanagimoto,T., Kimura, } \\
\text { T. and Kurosaka, K. }\end{array}$ & 2014 & AB907398.1 \\
\hline 3 & $\begin{array}{l}\text { Fakhri, F., Mahardika, G.N.K., Narayani, } \\
\text { I., Dewi, N.M.R.K., Cahyani, N.K.D., } \\
\text { Prayoga, I.M.A. and Yusmalinda, N.L.A. }\end{array}$ & 2014 & KM094131.1 \\
\hline 4 & Menezes, M.R., Kumar G, Kunal SP & 2012 & JF752061.1 \\
\hline
\end{tabular}

\subsection{Ekstraksi, Polymerase Chain \\ Reaction (PCR), Elektroforesis dan Sekuensing DNA}

Sampel genetik diekstraksi dengan cairan Chelex 10\% (Walsh et al., 1991). Sirip pektoral kemudian di ekstraksi untuk memperoleh sampel DNA (Akbar et al., 2018). Tahapan ekstraksi dimulai dengan memasukkan sampel ke dalam tube, setelah itu proses vortex dan sentrifuge selama +20 detik, setelah itu dilanjutkan pada tahapan heating blok (pemanasan) dengan suhu $95^{\circ} \mathrm{C}$ selama +45 menit. Proses berikutnya adalah tube divortex dan disentrifuge \pm 20 detik (Akbar et al., 2014). Amplifikasi DNA pada lokus control region menggunakan metode DNA sequencing dengan primer CRK-CRE (Lee et al., 1995). Proses PCR dimulai pada fase denaturasi awal $94{ }^{\circ} \mathrm{C} \pm 15$ detik, denaturasi $94{ }^{\circ} \mathrm{C}$ selama 30 detik, annealing pada $50{ }^{\circ} \mathrm{C} \pm 30$ detik dan extension pada 72 ${ }^{\circ} \mathrm{C} \pm 45$ detik dan selama $72{ }^{\circ} \mathrm{C}$ untuk 5 menit berikutnya dan pengulangan terjadi pada proses ini sebanyak 38 siklus.

Hasil amplifikasi DNA kemudian dilakukan elektroforesis untuk memperoleh kualitas produk DNA (Akbar et al., 2018). Elektroforesis dilakukan menggunakan gel agarose $1 \%$ melalui proses pencampuran $1 \mathrm{~g}$ agarosa pada erlenmeyer dan ditambahkan $100 \mathrm{~mL}$ TAE 1X, kemudian campuran diletakan pada microwave untuk dipanaskan. Larutan yang telah merata kemudian ditambahkan 4 uL EtBr. Gel agarose yang telah jadi selanjutnya dituangkan pada cetakan yang sebelumnya telah diletakan alat pembuat sumur kemudian didiamkan selama 30 menit.

Elektroforesis DNA melalui proses visualisasi menggunakan mesin ultraviolet (voltase $200 \mathrm{~V}$ dan arus $400 \mathrm{~mA}$ ) \pm 15 menit. Fragmentasi DNA yang telah berhasil selanjutnya disekuensing (Sanger et al., 1977). 


\subsection{Analisis Data Genetik}

Analisis sekuen DNA menggunakan

MEGA5 (Molecular Evolutionary Genetic Analysis) untuk rekonstruksi pohon filogenetik, analisis jarak genetik, distribusi dan probabilitas substitusi nukeotida (Tamura et al., 2011), dan Arlequin 3.5 (Excoffier \& Lischer, 2010) untuk melihat besarnya aliran genetik antar populasi (fiksasi indeks $(F s t)$ ).

\section{HASIL DAN PEMBAHASAN}

\subsection{Karakteristik Molekuler}

Karakteristik molekuler diperoleh pada 30 (data primer), 4 (data sekunder) dan 1 (sampel out group) sampel ikan cakalang memperoleh 546 panjang basa (bp) di daerah lokus control region DNA Mitokondria (mtDNA) (Table 2). Panjang fragmen yang mirip juga ditemukan Chow \& Kishino, (1995), Dammanggoda et al. (2011), Menezes et al. (2012), Jackson et al. (2014), Johnson et al. (2015) dan Fakhri et al. (2015).

Panjang fragmen yang ditemukan jika dibandingkan, maka lebih panjang dengan penelitian lainnya (Table 2). Panjang basa (bp) yang berbeda dimungkinkan jumlah sampel berbeda, produk kualitas DNA, primer yang belum spesifik, panjang ukuran dan komposisi basa primer, pengaruh lingkungan, kualitas makanan serta faktor hereditas, namun tidak menunjukkan pengaruh dari hasil sekuen (Williams et al., 1990;
Shizuka \& Lyon, 2008; Akbar et al., 2014; Jefri et al., 2015; Akbar et al., 2018). Mutasi genetik juga dapat memengaruhi perbedaan panjang basa DNA pada spesies. Hal ini biasanya disebut mutasi titik dikarenakan banyaknya nukleotida yang bermutasi pada nukleotida tunggal (Xiao et al., 2007). Subtitusi nukelotida ditemukan pada setiap individu berdasarkan hasil pengamatan (Akbar et al., 2018)

\subsection{Struktur Populasi Genetik}

Informasi populasi genetik diperoleh melaui informasi jarak genetik dan Amova population pairwise (Fst). Jarak genetik dalam populasi ikan cakalang Morotai yakni 0,009 , Bacan dengan nilai 0,023 dan Halmahera Tengah yaitu 0,007 , sedangkan secara keseluruhan analisis jarak genetik dalam populasi ikan cakalang di perairan Maluku Utara adalah 0,014 (Table 3). Kedekatan genetik pada ikan sejenis juga dilaporkan Graves et al. (1984) di Atlantik dan Pasifik, Ely et al. (2005) di Atlantik dan Pasifik, Dammannagoda et al. (2011) Samudra India.

Analisis jarak genetik antar populasi ikan cakalang berdasarkan data primer dan sekunder menunjukkan kedekatan genetik antar populasi (Table 3). Kedekatan genetik memberikan dugaan populasi ikan cakalang merupakan satu keturunan. Analisis jarak genetik antar populasi ikan cakalang data sekunder dan data primer (Tabel 3) ditemu-

Table 2. Samples, total samples, base pairs (bp), location and research sources.

\begin{tabular}{cccll}
\hline Sample & $\begin{array}{c}\text { Total } \\
\text { samples }\end{array}$ & $\begin{array}{c}\text { Base pairs } \\
(\text { bp })\end{array}$ & \multicolumn{1}{c}{ Locations } & \multicolumn{1}{c}{ Research Sources } \\
\hline \multirow{6}{*}{ Skipjack } & 30 & 546 & North Maluku Sea & Research result, 2018 \\
& 4 & 400 & East Hindia Ocean & Chow \& Kishino, 1995 \\
& 115 & 394 & Atlantic and Pasific & Ely et al., 2005 \\
& 324 & 488 & North west Indian Ocean & Dammanggoda et al., 2011 \\
& 175 & 508 & India Sea & Menezes et al., 2012 \\
& 35 & 500 & Indonesia islands & Jackson et al., 2014 \\
& 60 & 532 & Tanzania Coastal & Johnson et al., 2015 \\
& 1 & 517 & North Maluku Sea & Fakhri et al., 2015 \\
\end{tabular}


kan bahwa jarak genetik Morotai dengan Sulu-Celebes dan South China Sea yaitu 0,037, Morotai dengan Bali yaitu 0,052, Morotai dengan Indian Coast yakni 0,005 dan Morotai dengan Kyushu Island Japan sebesar 0,056. Hasil analisis lainnya ditemukan jarak genetik antar populasi Bacan dengan Sulu-Celebes dan South China Sea yakni 0,038, Bacan dengan Bali dengan nilai 0,052, Bacan dengan Indian Coast yaitu 0,014 dan Bacan dengan Kyushu Island Japan sebesar 0,056. Jarak genetik antar populasi Halmahera Tengah dengan SuluCelebes dan South China Sea sebesar 0,035, Halmahera Tengah dengan Bali yakni 0,050, Halmahera Tengah dengan Indian Coast yaitu 0,004 dan Halmahera Tengah dengan Kyushu Island Jepang adalah 0,054.

Analisis jarak genetik antar populasi data sekunder ditemukan bahwa jarak genetik Sulu-Celebes dan South China dengan Bali adalah 0,043, Sulu-Celebes dan South China dengan Indian Coast dengan nilai 0,031, Sulu- Celebes dan South China dengan Kyushu Island Japan sebesar 0,039. Jarak genetik antar populasi Bali dengan Indian Coast yaitu 0,046, Indian Coast dengan Kyushu Island Japan adalah 0,050 dan Bali dengan Kyushu Island Japan sebesar 0,055. Letak geografis ternyata tidak memberikan pengaruh terhadap aliran genetik populasi ikan cakalang. Populasi yang tersebar secara geografis memiliki hubungan struktur genetik satu dengan lainnya (Michels et al., 2001). Toha et al. (2014) sampel genetik yang acak setiap kelompok populasi menunjukan terdapat aliran gen dari satu daerah ke yang lainnya. Secara keseluruhan hasil yang diperoleh menunjukkan tidak terdapat diferensiasi genetik antar populasi ikan cakalang, meskipun memiliki jarak lokasi yang berbeda-beda. Sehingga memberikan gambaran bahwa terdapat kedekatan yang kuat antar populasi. Kedekatakan genetik dimungkinkan akibat dari sifat migrasi yang tinggi pada ikan cakalang sehingga memberikan peluang bertemu dengan populasi lain dan melakukan perkawinan. Hal ini akan mengakibatkan terciptanya aliran genetik antar populasi. Selain itu bisa diakibatkan karena jumlah populasi yang sangat besar di perairan sehingga terdistribusi secara luas di semua perairan.

Analisis fiksasi indeks (Fst) (Table 4) menunjukkan bahwa tidak terdapat diferensiasi genetik antar populasi. Tingginya nilai fiksasi indeks $(F s t)$ menunjukkan bahwa terjadi aliran genetik yang tinggi antar populasi. Hasil analisis diperoleh fiksasi indeks (Fst) Morotai dengan Bacan yaitu 0,995, Morotai dengan Halmahera Tengah yakni 0,991, Bacan dengan Halmahera Tengah yaitu 0,921. Sedangkan nilai (Fst) antar data primer dan data sekunder memperlihatkan

Table 3. Genetic distance between population skipjack in North Maluku Sea and secondaries data. Secondaries data: Sulu-Celebes and South China Sea, Bali, Indian coast, Kyushu Island Japan.

\begin{tabular}{ccccccccc}
\hline \multirow{2}{*}{ No. Locations } & \multicolumn{9}{c}{ Between populations } \\
\cline { 3 - 9 } & $\mathrm{Mo}$ & $\mathrm{Ba}$ & $\mathrm{HT}$ & $\mathrm{Su}$ & $\mathrm{BL}$ & $\mathrm{IC}$ & $\mathrm{KI}$ \\
\hline 1 & Morotai & - & - & - & - & - & - & - \\
2 & Bacan & 0.017 & - & - & - & - & - & - \\
3 & Halmahera Tengah & 0.009 & 0.018 & - & - & - & - & - \\
4 & Sulu-Celebes and South Cina & 0.037 & 0.038 & 0.035 & - & - & - & - \\
5 & Bali & 0.052 & 0.052 & 0.050 & 0.043 & - & - & - \\
6 & Iindian Coast & 0.005 & 0.014 & 0.004 & 0.031 & 0.046 & - & - \\
7 & Kyushu Island Japan & 0.056 & 0.056 & 0.054 & 0.039 & 0.055 & 0.050 & - \\
\hline
\end{tabular}

Information: $M o=$ Morotai; Ba= Bacan; HT= Halmahera Tengah; Su= Sulu-Celebes and South China Sea; BL=Bali; IC= Indian Coast; KI= Kyushu Island Japan. 
hal yang sama dimana terdapat aliran genetik yang besar. Nilai $(F s t)$ Morotai dengan SuluCelebes dan South China Sea yaitu 0,902, Morotai dengan Bali adalah 0,923, Morotai dengan India Coast yakni 0,801 dan Morotai dengan Kyushu Island Japan sebesar 0,818 (Table 4). Nilai (Fst) antar populasi Bacan dengan Sulu-Celebes dan South China Sea yaitu 0,908, Bacan dengan Bali adalah 0,934, Bacan dengan Kyushu Island Japan yakni 0,812 (Table 4). Aliran genetik berdasarkan nilai (Fst) diperoleh populasi Halmahera Tengah dengan Kyushu Island Japan adalah 0,901, Halmahera tengah dengan Bali dengan nilai 0,936, Halmahera Tengah dengan Indian Coast yakni 0,810 dan Halmahera Tengah dengan Kyushu Island Japan yakni 0,854 .

Hasil analisis fiksasi indeks (Fst) pada setiap data sekunder diperoleh Kyushu Island Japan dengan Bali adalah 0,878, Kyushu Island Japan dengan Indian Coast yakni 0,898, Sulu-Celebes dan South China Sea dengan Bali yaitu 0,818, Sulu-Celebes dan South China Sea dengan Indian Coast yakni 0,823, Sulu-Celebes dan South China Sea dengan Kyushu Island Japan yaitu 0,834, India Coast dengan Bali sebesar 0,844 (Table 4). Beberapa penelitian menunjukkan hasil yang sama, Dammannagoda, (2007) diperairan Sri Lanka, Menezes et al. (2012) di Indian Coast, dan Jackson et al. (2014) di beberapa kepulauan Indonesia.

Aliran genetik yang ditemukan dari ikan cakalang menggambarkan bahwa kesuluruhan populasi saling memberikan pengaruh. Distribusi besar di daerah Samudra mengindikasikan bahwa ukuran populasi yang besar pada ikan cakalang (Menezes et $a l .$, 2012). Hal ini tentunya memberikan efek aliran genetik antar populasi. Fakhri et al. (2015) mengatakan pola umum genetik yang ditemukan merupakan ciri populasi ikan cakalang dunia yang sangat bervariasi dan terjadi pencampuran antar populasi pada saat migrasi dalam rentang laut yang luas. Namun beberapa faktor pembatas aliran genetik seperti pola arus, perubahan temperatur dan salinitas atau pembatas alam (physical barrier) antar kontinen atau masa tanah Samudra (Chow \& Ushiama, 1995; Menezes et al., 2012).

Perairan dunia dipengaruhi sistem pola arus yang bergerak melintasi perairan antar Samudra. Pergerakan arus menyusuri perairan setiap negara kemudian terdistribusi secara lokal di setiap daerah. Indonesia dipengaruhi Arus Lintas Indonesia (Indonesian throughflow) yang masuk melewati Samudra Pasifik hingga menjulur ke Samudra Hindia (Gordon \& Fine, 1996). Aliran masa air Arus Lintas Indonesia masuk melalui dua jalur utama yang bersentuhan langsung dengan perairan Maluku Utara

Table 4. Fixation index analysis (Fst) between populations North Maluku Sea and secondaries data.

\begin{tabular}{|c|c|c|c|c|c|c|c|c|}
\hline \multirow{3}{*}{ No. } & \multicolumn{8}{|c|}{ Fixation index analysis (Fst) } \\
\hline & \multirow{2}{*}{ Locations } & \multicolumn{2}{|c|}{ Primer data } & \multicolumn{5}{|c|}{ Secondaries data } \\
\hline & & Mo & $\mathrm{Ba}$ & HT & $\mathrm{Su}$ & BL & $\mathrm{IC}$ & $\mathrm{KI}$ \\
\hline 1 & Morotai & - & - & - & - & - & - & - \\
\hline 2 & Bacan & 0.995 & - & - & - & - & - & - \\
\hline 3 & Halmahera Tengah & 0.991 & 0.921 & - & - & - & - & - \\
\hline 4 & Sulu-Celebes and South Cina & 0.902 & 0.908 & 0.901 & - & - & - & - \\
\hline 5 & Bali & 0.923 & 0.934 & 0.936 & 0.818 & - & - & - \\
\hline 6 & Iindian Coast & 0.801 & 0.889 & 0.810 & 0.823 & 0.844 & - & - \\
\hline 7 & Kyushu Island Japan & 0.818 & 0.812 & 0.854 & 0.834 & 0.878 & 0.898 & - \\
\hline
\end{tabular}

Information: $M o=$ Morotai; Ba= Bacan; HT= Halmahera Tengah; Su= Sulu-Celebes and South China Sea; BL= Bali; IC=Indian Coast; KI= Kyushu Island Japan. 
yakni Laut Maluku dan Laut Halmahera (Figure 2). Masuknya aliran massa air ini diduga membawa air bersuhu hangat, dari Samudra Pasifik di lapisan termoklin (Atmadipoera \& Mubaraq, 2016). Hal ini tentunya memberikan keuntungan bagi perairan Maluku Utara, dikarenakan faktor fisika dan kimia mambantu ikan pelagis seperti tuna dan cakalang untuk menjadikan perairan ini sebagai habitat untuk hidup menetap ataupun sebagai jalur migrasi. Bahri et al. (2017) mengatakan kepulauan bagian timur sangatlah unik karena ada sejumlah faktor fisik dan kimia yang dipengaruhi Samudra Pasifik karena daerah ini memang berbatasan langsung dengan Samudra ini.

Keseluruhan hasil analisis struktur genetik memperlihatkan kondisi ikan cakalang dalam keadaan normal (strong) di perairan Maluku Utara, walaupun tingkat ekploitasi cukup tinggi, namun kebugaran (fitness) ikan secara genetik masih sangat baik. Aliran genetik yang tinggi memperlihatkan bahwa keadaan populasi sangat stabil. Pengetahuan akan populasi genetik sangat penting, untuk melihat seberapa besar popu- lasi dapat bertahan dari perubahan lingkungan yang terjadi. Pengetahuan nilai biomassa merupakan unsur utama dalam penentuan stok, potensi perikanan dan sebagai dasar dalam penentuan upaya pengelolaan perikanan kedepan (Ma'mun et al., 2018). Aktivitas perikanan tangkap merupakan tempat bergantung kehidupan nelayan, sehingga perlu dikelola untuk keberlanjutan dan kelestarian perikanan (Yulianto et al., 2016). Aktivitas tangkap yang dilakukan berlebihan turut memberikan dampak terhadap populasi. Wigati et al. (2003) mengatakan kegiatan penangkapan secara terus menerus tanpa regulasi yang kuat memberikan ancaman pada lingkungan, populasi dan variasi genetik.

\subsection{Genetik Sebagai Basis Data Konservasi}

Informasi genetik populasi ikan cakalang memperlihatkan tidak terdapat diferensiasi antar populasi dan aliran genetik tinggi antar populasi (Table 3 dan 4). Hal ini menunjukkan bahwa ikan cakalang merupakan populasi panmictic. Populasi panmictic adalah suatu kondisi dimana semua individu

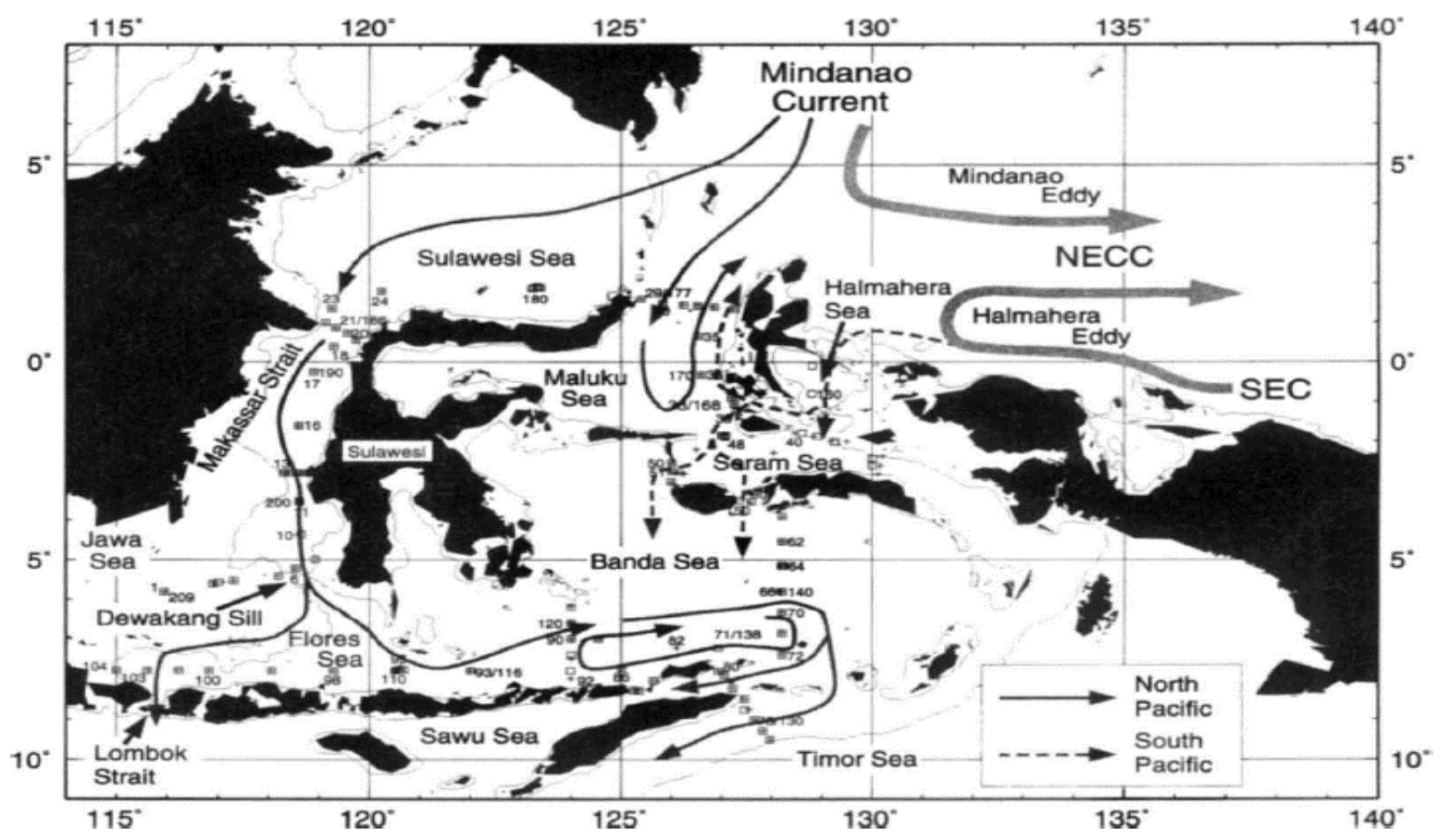

Figure 2. Indonesia through flow (Gordon \& Fine, 1996). 
berpotensi menjadi pasangan, tidak ada hambatan perkawinan baik secara genetik mau pun tingkah laku sehingga memungkinan semua kombinasi (Bahagiawati et al., 2006; 2010). Penelitian yang menemukan bahwa kelompok ikan tuna adalah populasi panmictic (Chiang et al., 2008) Akbar et al., 2014; Aris et al., 2017 dan juga pada ikan cakalang (Fakhri et al., 2015).

Status ikan cakalang berdasarkan IUCN belum masuk dalam kategori apendiks spesies (Table 5). Aktivitas penangkapan tinggi setiap tahun, perlu diperhatikan dikarenakan dapat mengakibatkan keberlanjutan dan kelestarian sumber daya tidak seimbang. Intensitas penangkapan yang tinggi dapat menurunkan populasi. Tindakan untuk mengantisipasi hal tersebut diperlukan suatu program konservasi untuk melindungi ikan dari kelangkaan dan dapat dilakukan melalui konservasi genetik. Status ikan tuna yang masuk kategori apendiks I dan II, memberikan gambaran bahwa spesies yang sering diekploitasi dalam skala besar untuk komersial, namun berbeda dengan ikan cakalang yang belum masuk dalam kategori apendiks, akan tetapi ekploitasi ikan ini sangat tinggi di Indonesia. KKP (2015) melaporkan bahwa komoditas perikanan penyumbang nilai ekspor perikanan Indonesia adalah tuna, tongkol dan cakalang. Aktivitas tangkap yang berlebih memberikan peluang penurunan populasi ikan. Jamal et al. (2014) mengatakan bahwa Tingkat pemanfaatan ikan Cakalang dengan alat tangkap pole and line di Kab. Luwu telah melampui nilai Maximum Sustainable Yield (MSY). Gigentika et al. (2014) menemukan produksi yang menurun dan kekhawatiran terhadap status sumber daya ikan cakalang di Kab. Lombok Timur.

Data genetik yang diperoleh pada penelitian yang dilakukan dapat dijadikan sebagai basis data untuk kelestarian yang berkelanjutan pada sumber daya hayati. Pemeliharaan genetik diatur dalam Permen No. 60 tahun 2007 berkaitan konservasi sumber daya ikan. Penjelasan PP No. 60 Tahun 2007 bahwa konservasi sumber daya ikan dilakukan berdasarkan asas manfaat, keadilan, kemitraan, pemerataan, keterpaduan, keterbukaan, efisiensi dan kelestarian yang berkelanjutan. Selain itu dijelaskan proses pembiakan pada ikan dilindungi dan jenis ikan tidak dilindungi dilakukan untuk menjaga kemurnian genetik ikan (PP No. 60 Tahun 2007).

UU No. 5 Tahun 1990 menjelaskan tiga sasaran konservasi, yaitu 1). Menjamin terpeliharanya proses ekologis yang menunjang sistem penyangga kehidupan bagi kelangsungan pembangunan dan kesejahteraan manusia (perlindungan sistem penyangga kehidupan); 2). Menjamin terpeliharanya keanekaragaman sumber genetik dan tipe-tipe ekosistemnya sehingga mampu menunjang pembangunan, ilmu pengetahuan, dan teknogi untuk kebutuhan manusia dalam menggunakan sumber daya alam hayati bagi ke-

Table 5. Tuna status in Red List International Union for Conservation of Nature (IUCN).

\begin{tabular}{llc}
\hline Category & Species Tuna & Status \\
\hline Extinct & - & \\
Extinct in the wild & - & \\
Critically endangered & Thunnus orientalis & Apendix I \\
Endangered & Thunnus thynnus and Thunnus & \\
& maccoyii & \\
Vulnerable & Thunnus obesus & Apendix II \\
Near threatened & Thunnus albacares & \\
Least concern & - & \\
Data deficient & - & \\
Not evaluated & Katsuwonus pelamis & \\
\hline
\end{tabular}


sejahteraan (pengawetan sumber plasma nutfah); 3). Mengendalikan cara pemanfaatan sumber daya alam hayati sehingga terjamin kelestariannya. Akibat sampingan ilmu pengetahuan dan teknologi yang kurang bijaksana, belum harmonisnya penggunaan dan peruntukan tanah serta belum berhasilnya sasaran konservasi secara optimal, baik di darat maupun di perairan dapat mengakibatkan timbulnya gejala erosi genetik, polusi, dan penurunan potensi sumber daya alam hayati.

Tingginya keragaman genetik pada ikan cakalang di wilayah laut Maluku Utara, memberikan informasi bahwa populasi cakalag memiliki kemampuan berdaptasi lingkungan yang dinamis dan tekanan ekploitasi. Variasi genetik tinggi memberikan gambaran terhadap stuktur genetik populasi yang belum terganggu. Data genetik ikan cakalang yang diperoleh perlu mendapatkan perhatian sebagai upaya menjaga, melestarikan dan melanjutkan keberlangsungan sumber daya ikan di perairan Maluku Utara. Data genetik juga dijadikan sebagai basis data dan pengelolaan berkelanjutan, dikarenakan dapat memberikan penjelasan tentang kondisi ikan saat ini. Adanya berbagai macam gen dari individu-individu di dalam populasi panmictic menambah kemampuan populasi dalam merespon perubahan lingkungan.

Strategi dalam upaya mempertahankan kualitas genetik perlu dilakukan dengan cara melestarikan keragaman genetik dengan menerapkan regulasi tentang pelaksanaan batas ukuran minimum tangkapan pada setiap operasi penangkapan. Ikan yang dapat dimanfaatkan telah memasuki fase dewasa berdasarkan biomorfologi. Kedua adalah regulasi waktu tangkap, sebagai contoh operasi tangkap dilakukan pada musim puncak atau dapat dilakukan selama 6 bulan. Penerapan seperti ini dapat overfishing, sehingga stok sumber daya tetap terjamin kelestarianya. Ketiga adalah penetapan kawasan reservasi (reservation region) yang dibentuk berdasarkan kesepakatan masyara- kat lokal dan peraturan pemerintah. Pembentukan wilayah reservasi diperlukan dan bersifat penting untuk kegiatan konservasi genetik, dengan bertanggung jawat terhadap kelangsungan hidup populasi ikan.

\section{KESIMPULAN}

Hasil penelitian karakteristik molekuler diperoleh pada 30 (data primer), 4 (data sekunder) dan 1 (sampel out group) sampel ikan cakalang memperoleh 546 (base pairs) di control region DNA Mitokondria (mtDNA). Secara keseluruhan hasil analisis jarak genetik antar populasi ikan cakalang berdasarkan data primer dan sekunder menunjukkan adanya kedekatan jarak genetik antar populasi dan aliran genetik yang kuat. Data genetik yang diperoleh dapat dijadikan sebagai basis data konservasi untuk keberlanjutan dan pelestarian populasi ikan cakalang di masa akan datang.

\section{UCAPAN TERIMA KASIH}

Terima kasih kepada Kemenristekdikti yang telah memberikan hibah Penelitian Dosen Pemula (PDP) tahun 2018. Penulis juga menyampaikan terima kasih kepada Pemerintah Daerah di Provinsi Maluku Utara atas bantuannya dalam pelaksanaan penelitian. Tak lupa Peneliti mengucapkan terima kasih secara khusus kepada Bapak Sukarmin Idrus S.Pi., M.Si., Rudi Mansur, S.Pi. dan Muhajirin Ahmad, S.Pi. atas kontribusinya dalam penelitian.

\section{DAFTAR PUSTAKA}

Akbar, N., N.P. Zamani, \& H.H. Madduppa. 2014. Keragaman genetik ikan tuna sirip kuning (Thunnus albacares) dari dua populasi di Laut Maluku, Indonesia. J. Depik, 3(1): 65-73. http://doi.org/10.13170/depik.3.1.130 4

Akbar, N., M. Aris, M. Irfan, I. Tahir, A. Baksir, Surahman, H.H. Madduppa, 
\& R. Kotta. 2018. Filogenetik ikan tuna (Thunnus spp.) di Perairan Maluku Utara, Indonesia. J. Iktiologi Indonesia, 18(1): 1-11. http://doi.org/10.32491/jii.v18i1.37

Akbar, N. \& R. Labenua. 2018. Keragaman genetik ikan cakalang (Katsuwonus pelamis ) di Perairan Laut Maluku Utara. J. Depik, 7(2): 164-176. http://doi.org/10.13170/depik.7.2.111 56

Aris, M., N. Akbar, \& R. Labenua. 2017. Genetic and phylogenetic variations of yellowfin tuna (Thunnus albacares) as a basis for sustainable fishery resources management in North Moluccas. International $J$. Pharma Bio Science, 8(4): 419-426. http://doi.org/10.22376/ijpbs.2017.8.4 .b419-426

Atmadipoera, S.A. \& G.I. Mubaraq. 2016. Struktur dan variabilitas arlindo di laut Sulawesi. J. Kelautan Nasional, 11(3): 159-174.

http://doi.org/10.15578/jkn.v11i3.611 6

Bahagiawati, D.W., Buchari, Nurindah, H.H. Rizjaani, D.W. Utami, B. Sahari, \& A. Sari. 2006. Struktur populasi Trichogrammatoidea armigera, parasitoid telur Helicoverpa armigera, berdasarkan analisis RAPD-PCR. J. AgroBiogen, 2(2): 5258.

http://doi.org/10.21082/jbio.v2n2.200 6.p5259

Bahagiawati, D.W., Utami, \& D. Buchari. 2010. Pengelompokan dan struktur populasi parasitoid telur Trichogrammatoidea armigera pada telur Helicoverpa armigera pada jagung berdasarkan karakter molekuler. J. Entomologi Indonesia, 7(1): 54-65.

http://doi.org/10.5994/jei.7.1.54

Bahri, S., A.S. Atmadipoera, \& H.H. Madduppa. 2017. Keragaman genetik penyu lekang Lepidochelys olivacea dengan pola arus di teluk Cendrawasih, Papua. J. Ilmu dan Teknologi Kelautan Tropis, 9(2): 747760.

http://doi.org/10.29244/jitkt.v9i2.193 07

Chiang, H.C., C.C. Hsu, H.D. Lin, G.C. Ma, T.Y. Chiang, \& H.Y. Yang. 2006. Population structure of bigeye tuna (Thunnus obesus) in the South China Sea, Philippine Sea and western Pacific Ocean inferred from mitochondrial DNA. Fisheries Research, 79(1): 219-225. http://doi.org/10.1016/j.fishres.2005.1 1.026

Chiang, H.C., C.C. Hsu, G.C.C. Wu, S.K. Chang, \& H.Y. Yang. 2008. Population structure of bigeye tuna (Thunnus Obesus) in the Indian Ocean inferred from mitochondrial DNA. Fisheries Research, 90(1): 305-312.

http://doi.org/10.1016/j.fishres.2007.1 1.006

Chow, S. \& H. Kishino. 1995. Phylogenetic relationships between tuna species of the genus Thunnus (Scombridae: Teleostei): inconsistent implications from morphology, nuclear and mitochondrial genomes. $J$. of Moleculer Evolution, 41(6): 741-748. http://doi.org/10.1007/BF00350321

Chow, S. \& H. Ushiama. 1995. Global population structure of albacore (Thunnus alalunga) inferred by RFLP analysis of the mitochondrial ATPase gene. Marine Biology, 123(1): 39-45. http://doi.org/10.1007/BF0035021

Dammannagoda, S.T., D.A. Hurwood, \& P.B. Mather. 2011. Genetic analysis reveals two stocks of skipjack tuna (Katsuwonus pelamis) in the northwestern Indian Ocean. Canadian J. of Fisheries and Aquatic Sciences, 68(2): 210-223.

http://doi.org/10.1139/F10-136 
Ely, B., J. Vinas, J.R.A. Bremer, D. Black, L. Lucas, K. Covello, A.V. Labrie, \& E. Thelen. 2005. Consequences of the historical demography on the global population structure of two highly migratory cosmopolitan marine fishes: the yellowfin tuna (Thunnus albacares) and the skipjack tuna (Katsuwonus pelamis). BMC Evolutionary Biology, 5(19): 1-9. http://doi.org/10.1186/1471-2148-519

Excoffier, L. \& H.E.L. Lischer. 2010. Arlequin suite ver 3.5; a new series of program to perform population genetik analysis under linux and windows. Molecular Ecology Resources, 10(3): 564-56. http://doi.org/10.1111/j.17550988.2010.02847.x

Fakhri, F., I. Narayani, \& I.G.N.K. Mahardika. 2015. Keragaman genetik ikan cakalang (Katsuwonus Pelamis) dari Kabupaten Jembrana dan Karangasem, Bali. J. Biologi, 19(1): 11-14.

http://ojs.unud.ac.id/index.php/BIO/ar ticle/view/16493

Gigentika, S., S.H. Wisudo, \& Mustaruddin. 2014. Strategi pengembangan perikanan cakalang di Kabupaten Lombok Timur Provinsi Nusa Tenggara Barat. Marine Fisheries, 5(1): 27-40. http://doi.org/10.29244/jmf.5.1.27-40

Gordon, A.L. \& R.A. Fine. 1996. Pathways of water between the Pacific and Indian oceans in the Indonesian seas. Nature, 379(6561): 146-149. http://doi.org/10.1038/379146a0

Graves, J.E., S.D. Ferris, \& A.E. Dizon. 1984. Close genetic similarity of Atlantic and Pacific skipjack tuna (Katsuwonus pelamis) demonstrated with restriction endonuclease analysis of mitochondrial DNA. Marine Biology, 79(3): 315-319. http://doi.org/10.1007/BF00393264
Jackson, A.M., M.V. Ambariyanto, Erdmann, A.H.A. Toha, L.A. Stevens, \& P.H. Barber. 2014. Phylogeography of commercial tuna and mackerel in the Indonesian Archipelago. Bulletin Marine Science, 90(1): 471-492.

http://doi.org/10.5343/bms.2012.1097

Jamal, M., Hasrun, \& Ernaningsih. 2014. Tingkat pemanfaatan dan estimasi potensi ikan cakalang (Katsuwonus pelamis) di kawasan teluk Bone. Torani, 24(2): 20-28. http://doi.org/10.35911/torani.v24i2.2 25

Johnson, M.G., Y.D. Mgaya, \& Y.W. Shaghude. 2015. Mitochondrial DNA analysis reveals a single stocks of frigate tuna Auxis thazard (Lacepède, $1800)$ in the northern coastal waters of Tanzania. Indian Ocean Tuna Commission-2015-WPNT05-16. 12 p.

Lee, W.J., J. Conroy, W.H. Howell, \& T.D. Kocher. 1995. Structure and evolution of teleost mitochondrial control regions. Moleculer Evolution, 41(1): 54-66. http://doi.org/10.1007/BF00174041

Ma'mun, A., A. Priatna, Suwarso, \& M. Natsir. 2018. Potensi dan distribusi spasial ikan demersal di Laut Jawa (WPPNRI-712) dengan menggunakan teknoogi hidroakustik. J. Ilmu dan Teknologi Kelautan Tropis, 10(2): 489-500.

http://doi.org/1029244/jitkt.v10i2.215 49

Menezes, M.R., G. Kumar, \& S.P. Kunal. 2012. Population genetic structure of skipjack tuna Katsuwonus pelamis from the Indian coast using sequence analysis of the mitochondrial DNA D-loop region. J. Fish Biology, 80(6): 2198-2212.

http://doi.org/10.1111/j.1095-

8649.2012.03270.x 
Michels, E., K. Cottenie, L. Neys, K. De Gelas, P. Coppin, \& L. De Meester. 2001. Geographical and genetic distances among zooplankton populations in a set of interconnected ponds: a plea for using GIS modelling of the effective geographical distance. Molecular Ecology, 10(8): 19291938. http://doi.org/10.1046/j.1365294X.2001.01340.x

Permana, G.N., J.H. Hutapea, Haryanti, \& S.B.M. Sembiring. 2007. Variasi genetik ikan tuna sirip kuning (Thunnus albaceras) dengan analisis elektroforesis allozyme dan mtDNA. J. Riset Akuakultur, 2(1): 41-50. http://doi.org/10.15578/jra.2.1.2007.4 $1-50$

Sanger, F., S. Nicklen, \& A.R. Coulson. 1977. DNA sequencing with chainterminating inhibitors. National Academical Science, United Stated of America, 74(12): 5463-5467. http://doi.org/10.1073/pnas.74.12.546 3

Shizuka, D. \& B.E. Lyon. 2008. Improving the reliability of molecular sexing using a W-specific marker. Molecular Ecology Resources, 8(6): 1249-1253. http://doi.org/10.1111/j.17550998.2008.02342.x

Soewardi, K. \& Suwarso. 2006. Variasi geografik dalam struktur genetik populasi ikan kakap merah, Lutjanus malabaricus (Lutjanidae) dan interaksi lingkungan di laut Jawa. $J$. Ilmu-Ilmu Perairan dan Perikanan Indonesia, 13(1): 69-75.

Suman A., H.E. Irianto, K. Amri, \& B. Nugraha. 2013. Population structure and reproduction of bigeye tuna (Thunnus Obesus) in Indian Ocean at western part of Sumatera and southern part of Java and Nusa Tenggara. Indian Ocean Tuna Commission, 8 oktober 2013. 1-14 pp.
Tamura, K., D. Peterson, N. Peterson, G. Stecher, M. Nei, \& S. Kumar. 2011. Mega 5: molecular evolutionary genetics analysis using maximum likehood, evolutionary distance and maximum parsimony method. Moleculer Biology Evolution, 28(10): 2731-2739. http://doi.org/10.1093/molbev/msr12 1

Toha, A.H.A., R. Binur, Suhaemi, Lutfi, L. Hakim, N. Widodo, \& S.B. Sumitro.2014. Genetic aspects of the commercially used sea urchin Tripneustes gratilla. A review. J. of Biological Researches, 20(2): 12-17. http://doi.org/10.23869/bphjr.20.1.20 143

Toatubun, N., J. Wenno, \& I.L. Labaro. 2015. Struktur populasi ikan cakalang hasil tangkapan pukat cincin yang didaratkan di pelabuhan perikanan pantai Tumumpa Kota Manado. J. Ilmu dan Teknologi Perikanan Tangkap, 2(2): 73-77.

http://doi.org/10.35800/jitpt.2.2.2015. 9234

Walsh, P.S., D.A. Metzger, \& R. Higuchi. 1991. Chelex-100 as a medium for simple extraction of DNA for PCR based typing from forensic material. Biotechniques, 10(4): 506-513. http://doi.org/10.2144/000114018

Wigati, E., Sutarno, \& Haryanti. 2003. Variasi genetik ikan anggoli (Pristipomoides multidens) berdasarkan pola pita allozim. Biodiversitas, 4(2): 73-79. http://doi.org/10.13057/biodiv/d0402 01 .

Williams, J.G.K., A.R. Kubelik, K.J. Livak, J.A. Rafalski, \& S.V. Tingey. 1990. DNA polymorphism amplified by arbitrary primers are useful as genetic markers. Nucleic Acids Research, 18(22): 6531-6535. http://doi.org/10.1093/nar/18.22.6531 
Xiao, M., P.M. Gordon, A. Phong, C. Ha,

T.F. Chan, D. Cai, P.R. Selvin, \& Y. Received : 21 January 2020

Kwok. 2007. Determination of Reviewed: 7 May 2020

haplotype for single DNA molecules: Accepted : 24 July 2020

a method for single molecules

barcoding. Human Mutation, 28(9):

913-921.

http://doi.org.10.1002/humu.20528 
